\title{
ON THE SOLUTION OF THE SETTING QUALITY PROBLEM FOR THE RELAY CONTROLLERS
}

\author{
S.V. Panferov', N.A. Trenin ${ }^{1}$, V.I. Panferov ${ }^{2}$ \\ ${ }^{1}$ Russian Air Force Military Educational and Scientific Center "Air Force Academy named after \\ Professor N.E. Zhukovsky and Y.A. Gagarin", Chelyabinsk branch, Russian Federation, \\ ${ }^{2}$ South Ural State University, Chelyabinsk, Russian Federation, tgsiv@mail.ru
}

\begin{abstract}
The paper considers a problem of setting the automatic control systems (ACS) including twoposition and three-position PID-controllers. The problem can be generally solved by a method of direct simulation analysis of transient response in ACS. To perform a parametric identification of the models of controlled objects, the numerical procedures of determining the optimal parameters of their differential equations have been developed for both experimental transient response curves and transient functions of the working closed systems. The algorithms of digital implementation for the relay controllers are presented. The results of process simulation in two-position and threeposition systems are analyzed. The outcomes of the research can be used to select the relay controller settings.
\end{abstract}

Keywords: automatic control system, relay controller, control object, parametric identification, setting quality, numerical computation, transient process, choice of settings.

\section{Introduction}

Today no one of the complex technological systems or objects can operate being non-automated. Automation provides high quality of the system and object operation as well as a considerable saving in power and material resources. The systems and objects are also known to have a significant number of controlled sections fitted with the positional executive units that can be replaced only under extremely disadvantageous conditions. In this case, even providing that there are modern microprocessor controllers with a large set of regulating algorithms in their libraries, the only possible solution of an automation problem is application of position PID-controllers [1-2]. It should be noted that the technical implement of the discrete outputs for controlling the positional executive units is much more accessible than the analog ones. As a result, the number of the control circuits maintained by a single controller increases substantially while the control system cost reduces as a whole.

\section{The control quality problem}

It is well known that the position PID-controllers usually operate in oscillatory mode (two-position controllers can work only in oscillatory regime) which is undesirable in terms of operating quality of the automatic control systems (ACS). The quality of ACS operation should be acceptable as it defines the automation efficiency. The problem is being solved by a choice of a controller settings. However, the approximate graphical or grapho-analytical methods are still used to estimate the dynamic parameters of the objects [3-5], so the problem of the setting calculation for such systems remains actual [6]. The accuracy of analysis and control circuit adjustment performed by using these methods does not meet modern requirements while the labour input is high. Therefore, it is reasonable to apply the direct simulation transient analysis to ACS by using computer. In this case the questions of the desired setting accuracy, complete transient analysis, and reducing the amount of relevant graphical layouts and manual calculations are settled.

\section{Parametric identification of the models of controlled objects}

The calculation of the controller settings begins with estimating the dynamic parameters of a control object, so let us consider the problem.

It is common knowledge that the dynamic properties of a great number of control objects can be presented by the following types of differential equations: 


$$
\begin{aligned}
& a_{1} d x(t) / d t+x(t)=k U(t-\tau) \\
& a_{2} d^{2} x(t) / d t^{2}+a_{1} d x(t) / d t+x(t)=k U(t-\tau),
\end{aligned}
$$

where $x(t)$ is a controlled coordinate, $U$ is a control action, $t$ is time, $\tau$ is delay time, $k$ is the transition factor of an object, $a_{1}$ and $a_{2}$ are the coefficients of the differential equations.

It is found that the differential equations describe the dynamic properties of specific objects with a desired accuracy only if the coefficients $a_{1}, a_{2}$, and $k$ as well as the delay time $\tau$ are determined satisfactorily (it is evident that for the model (1) there is no coefficient $a_{2}$ ). Let us consider a solution of the problem.

Suppose that an experimental transient response curve of a control object is known. Let us regard the information specified by the curve and the structure of the models (1) and (2) as initial data for solving an identification problem. An experimental response of the object to any input action $U$ can be basically used instead of the experimental transient response curve. Let us formulate the identification problem as follows. It is required to find the values of the coefficients $a_{1}, a_{2}, k$ and the delay time $\tau$ such that the identification criterion

$$
I\left(k, a_{1}, a_{2}, \tau\right)=\sum_{i=1}^{n}\left[x^{E}\left(t_{i}\right)-x\left(t_{i}\right)\right]^{2}
$$

has a minimal value. Here $x^{E}$ is an experimental value of the object output, $x$ is a calculated value which is determined from the model of the object (1) or (2) for equal input action $U, t_{i}$ are the time moments used for identification, $n$ is a number of experimental points.

The identification problem was solved with a program implementing the method of coordinate descent. The problems of one-dimensional minimization obtained in so doing were solved by golden section search subprogram. To perform a numerical integration of the equations (1) or (2), the Runge-Kutta method was applied with accuracy proportional to the quantic time step. It is obvious that in this case the differential equation (2) was previously presented as a set of first order differential equations that is a normal Cauchy form. To provide the desired calculation accuracy, the program is developed in such a way that each time interval between two experimental points contains an integer number of the calculated steps.

The developed identification procedure was tested for a large set of the experimental transient response curves given in [4-5]. In each case the identification results had an adequate quality level. For example, Fig. 1 shows both an experimental transient curve and the curve calculated by the adjusted differential equation, for the water-water heater through the "delivery water flow rate - temperature of the water leaving a heater" channel. The experimental curve is full and the calculated one is dashed.

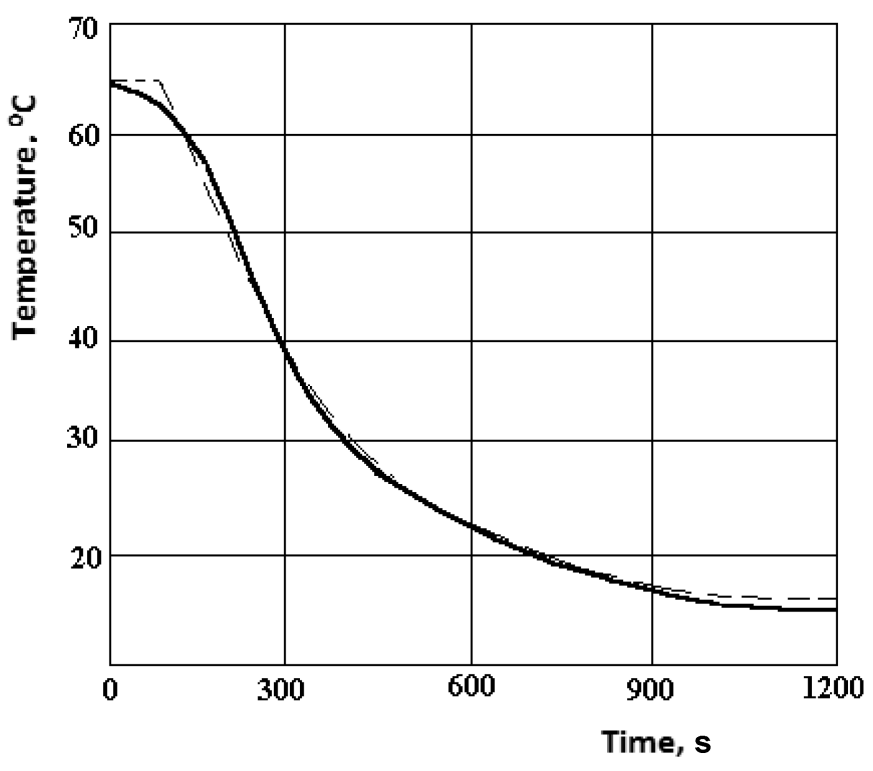

Fig. 1. Experimental and calculated transient curves for a water-water heater The heater with $108 \mathrm{~mm}$ body outside diameter had 6 series-connected sections each of which was $4 \mathrm{~m}$ in length. The heater entry temperatures of the delivery water and the water to be heated were 69 and $14{ }^{\circ} \mathrm{C}$ relatively. The flow rate of the water being heated was supported as a constant equal to $0.664 \mathrm{~kg} / \mathrm{s}$ while the delivery water flow was decreased from $1.14 \mathrm{~kg} / \mathrm{s}$ to $0 \mathrm{~kg} / \mathrm{s}$. In this case, the control object was described by a differential equation of a second type with the determined parameter values as follows:

$$
\begin{aligned}
& a_{1}=256 \mathrm{~s} ; a_{2}=999 \mathrm{~s}^{2} ; \tau_{o b}=62 \mathrm{~s} ; \\
& k_{o b}=43.85^{\circ} \mathrm{C} /(\mathrm{kg} / \mathrm{s}) .
\end{aligned}
$$

Here the mean-square deviation of the calculated curve from the experimental one $\sqrt{I / n}$ is equal to $0.42^{\circ} \mathrm{C}$, that is wholly satisfactory. 
The identification procedures for the dynamic properties of the control objects were developed from the transfer function of the operating ACS [7]. The necessity can be explained a follows.

The dynamic properties of the control objects are known to vary significantly when the operation mode is changed [7]. The greatest variation usually happens to the object's transition factor which numeric value can change by several times while in operation. The variability of the object's dynamic parameters results in the changes of regulation quality values in the systems with constant settings of the automated controllers when the operation mode varies. The attempts to define and apply the causeeffect relations for monitoring the dynamic parameter values in order to improve the regulation quality cannot solve the problem as a whole because of strong instability of interrelations [7]. In the circumstances, it seems appropriate to determine the dynamic parameters of the control channels and optimize the settings of the automatic controllers in the process of the furnaces operation. Thus, the dynamic properties of the control objects need to be determined while ACS works according to its response on the step input of the closed-loop transfer function [7-9]. At that, either the assigned disturbance or disturbance by regulating unit (load disturbance) is applied. The latest action can be organized by issuing the command of transferring the control loop to the manual control mode through the interface connection channel followed with a quick change of regulating unit position and immediate return to the automatic mode. It is clear that the mathematical model of the whole control loop is to be used in the case. It should be noted that the developed identification algorithms can be easily modified for a case when it is necessary to minimize a sum of the magnitudes of the differences between the calculated and experimental values of $x$ coordinate instead of the criterion (3). It can also be modified for the case of a minimax problem which requires to minimize the maximum deviation of the calculated values from the experimental ones. The criterion (3) is preferable considering that the parameter estimations obtained by minimizing the criterion are most credible. Besides, the use of integral identification criteria requires minor changes in the programs.

\section{Simulation of relay ACS}

While simulating, it was considered that two-position PID-controller forms control action as follows:

$$
U_{i}=\left\{\begin{array}{l}
U_{\min }, \text { if } \varepsilon \leq \varepsilon_{r e s}-\Delta ; \\
U_{\max }, \text { if } \varepsilon \geq \varepsilon_{r e s} ; \\
U_{i-1}, \text { if } \varepsilon_{r e s}-\Delta<\varepsilon<\varepsilon_{r e s} .
\end{array}\right.
$$

Here $\varepsilon$ is an actuating signal calculated by a standard system comparison component, that is, by a formula $\varepsilon(t)=x^{s v}(t)-x(t)$, where $x^{s v}(t)$ is a set value of the adjustable technological parameter, $\varepsilon_{\text {res }}$ is a response value of PID-controller, $\Delta$ is a width of a hysteresis loop, $U_{\min }$ and $U_{\max }$ are minimum and maximum of control action values, respectively, $i$ is a number of a calculated time step.

The response value $\varepsilon_{\text {res }}$ and the width of a hysteresis loop $\Delta$ are viewed as the setting parameters of two-position PID-controller.

An operation algorithm of three-position controller is as follows.

$$
U_{i}=\left\{\begin{array}{l}
U_{\min }, \text { if } \varepsilon \leq \varepsilon_{0} ; \\
U_{i-1}, \text { if } \varepsilon_{0}<\varepsilon<\left(\varepsilon_{0}+\Delta_{0}\right) ; \\
U_{a v e}, \text { if }\left(\varepsilon_{0}+\Delta_{0}\right) \leq \varepsilon \leq\left(\varepsilon_{1}-\Delta_{1}\right) ; \\
U_{i-1}, \text { if }\left(\varepsilon_{1}-\Delta_{1}\right)<\varepsilon<\varepsilon_{1} ; \\
U_{\max }, \text { if } \varepsilon \geq \varepsilon_{1} .
\end{array}\right.
$$

Static characteristic of three-position controller with a description of the added designations is given in Fig. 2. The transient analysis of two-position ACS for an object with the dynamic properties presented in Fig. 2 demonstrated that, for example, when $x^{s v}(t)=60^{\circ} \mathrm{C}, U_{\min }=0 \mathrm{~kg} / \mathrm{s}, U_{\max }=2 \mathrm{~kg} / \mathrm{s}$, $\varepsilon_{\text {res }}=1{ }^{\circ} \mathrm{C}, \Delta=2{ }^{\circ} \mathrm{C}$ the positive amplitude length (the length of time span where $U_{i}=U_{\max }$ ) was equal to $181 \mathrm{~s}$, and the negative amplitude length (the length of time span where $U_{i}=U_{\min }$ ) was equal to $99 \mathrm{~s}$. 


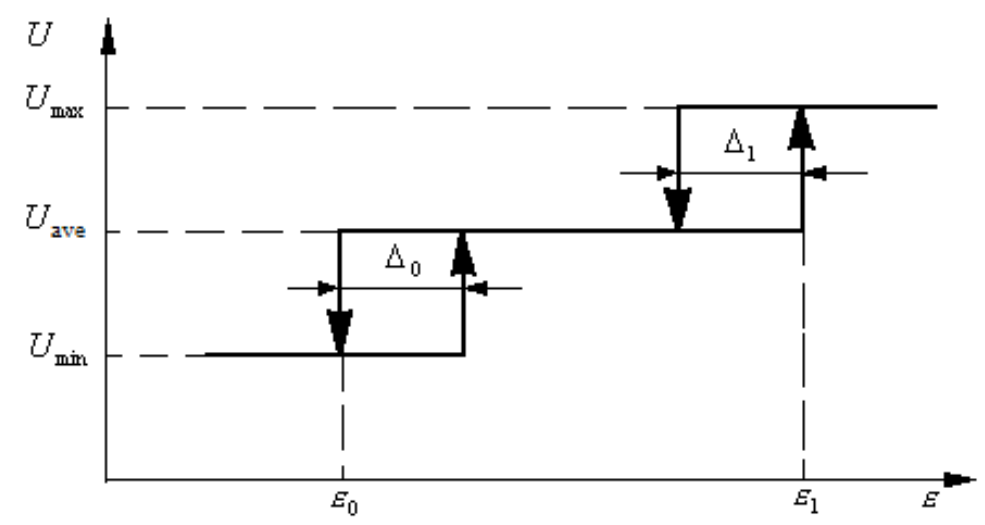

Fig. 2. Static characteristic of three-position controller

The positive amplitude of the controlled value deviation from the preset value was $6.8^{\circ} \mathrm{C}$ in the case while the negative one was $14.0^{\circ} \mathrm{C}$. The controlled value average was equal to $56.4{ }^{\circ} \mathrm{C}$ meaning that there was a sustained deviation of the controlled value average from the preset value. To remove the error, the settings for the controller were corrected.

Decrease of the two-position controller settings $\varepsilon_{\text {res }}$ and $\Delta$ to $0{ }^{\circ} \mathrm{C}$ resulted in slight changes of the values of the control quality level. The length of the positive amplitude decreased to $170 \mathrm{~s}$ while the negative one came to $90 \mathrm{~s}$. At that, the positive amplitude of the controlled value deviation from the preset value was equal to $5.9^{\circ} \mathrm{C}$ while the negative one was $13.1^{\circ} \mathrm{C}$.

The presented values of the control quality level are strongly due to the high value of the control object delay time $\tau$. So, the transient analysis for the same conditions as those in the first case but at $\tau=0 \mathrm{~s}$ showed that the length of the positive amplitude decreased to $30 \mathrm{~s}$ while the negative one came to $15 \mathrm{~s}$. At that, the positive amplitude of the controlled value deviation from the preset value was equal to $1.1^{\circ} \mathrm{C}$ while the negative one was only $1.3^{\circ} \mathrm{C}$.

The simulation also showed that the method of partial inflow (when $U_{\min } \neq 0$ because of applying bypass) under two-position control allows achieving acceptable control quality in each case. For example, when $x^{s v}(t)=60^{\circ} \mathrm{C}, U_{\min }=1 \mathrm{~kg} / \mathrm{s}, U_{\max }=2 \mathrm{~kg} / \mathrm{s}, \varepsilon_{\text {res }}=1{ }^{\circ} \mathrm{C}, \Delta=2{ }^{\circ} \mathrm{C}$ the length of the positive amplitude was only $105 \mathrm{~s}$ and the length of the negative amplitude achieved $170 \mathrm{~s}$. In this case, the positive amplitude of the controlled value deviation from the preset value was equal to $6.8^{\circ} \mathrm{C}$ and the negative

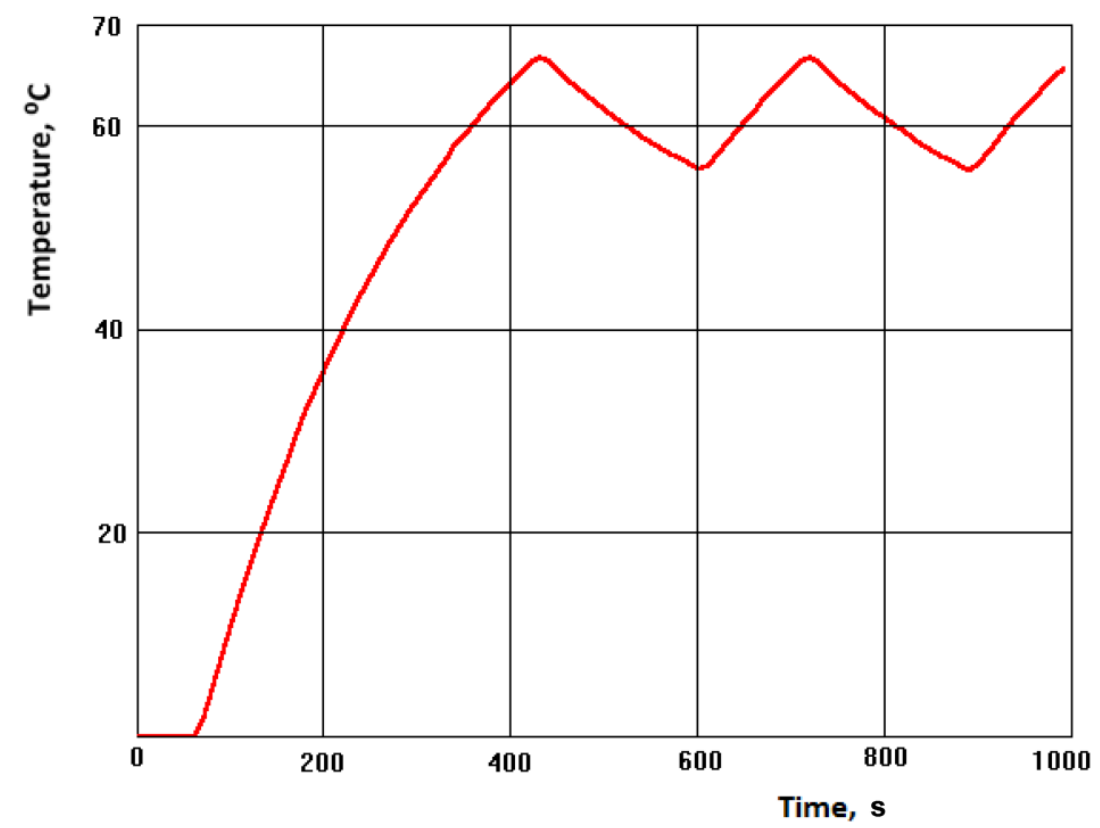

Fig. 3. Transient process in the two-position ACS one became $4.3^{\circ} \mathrm{C}$. The controlled value average was equal to $61.3{ }^{\circ} \mathrm{C}$. Thus the control quality was noticeably improved. The transient process specific to this case is demonstrated in Fig. 3. The ways to improve the control quality in two-position ACS are presented in the papers [10-14].

The advantages of the threeposition control are well-known [1-3]. Firstly, it is a possibility to obtain a non-oscillatory transient process and secondly, all things being equal, it is a lower value of both amplitude and frequency of the self-sustained oscillations. In Fig. 4 there is a graph of the non-oscillatory transient process under the three- 
position temperature control in a hot water system with a heater which dynamic properties are presented in Fig. 1. This transient process was achieved under the following settings of the controller:

$x^{s v}(t)=60^{\circ} \mathrm{C}, U_{\min }=0 \mathrm{~kg} / \mathrm{s}$,

$U_{\text {ave }}=1.36 \mathrm{~kg} / \mathrm{s}, U_{\max }=2 \mathrm{~kg} / \mathrm{s}$,

$\varepsilon_{1}=5^{\circ} \mathrm{C}, \Delta_{1}=0,5^{\circ} \mathrm{C}$,

$\varepsilon_{0}=-5^{\circ} \mathrm{C}, \Delta_{0}=0,5^{\circ} \mathrm{C}$.

Consequently, the using of the three-position controllers in the automatic control systems is more preferable.

\section{Conclusion}

The parametric identification procedure for the dynamic prop-

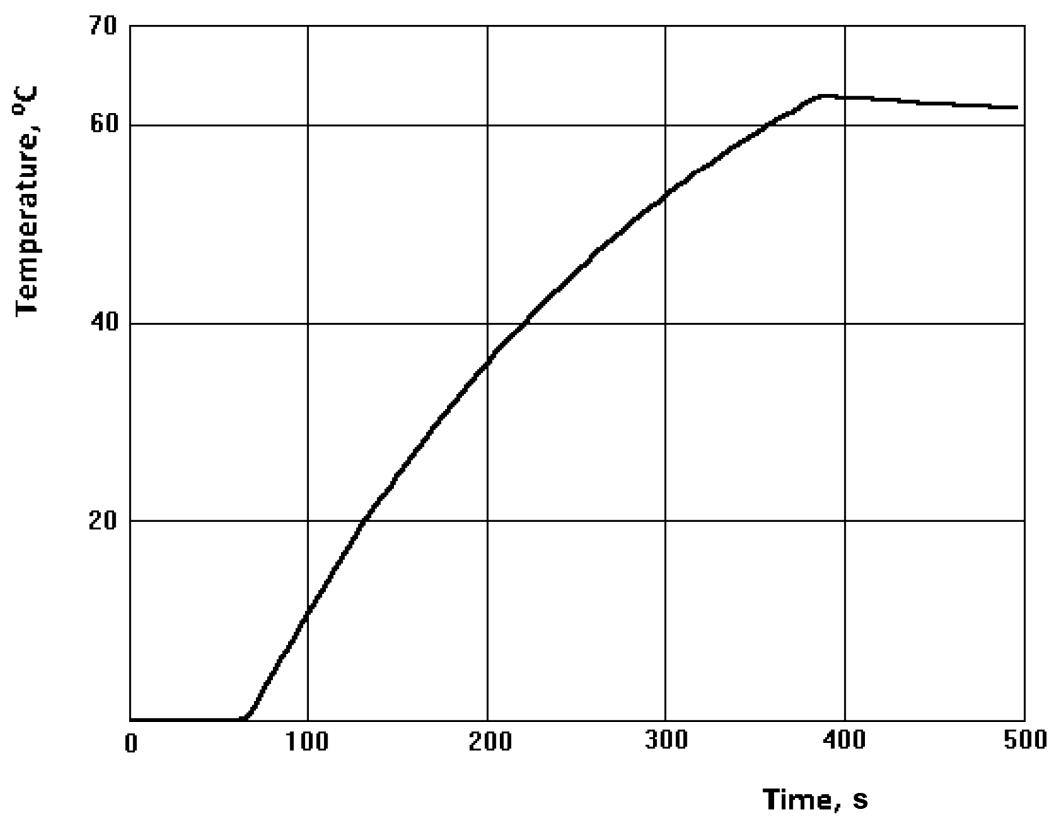

Fig. 4. Transient process in the three-position ACS erties of the control objects, and the computational models of the two-position and three-position automatic control systems have been developed. The developed models are recommended for analyzing a system setting quality and choosing the parameters of the controller settings.

\section{References}

1. Kaganov V.Yu., Glinkov G.M., Klimovitskiy M.D., Klimushkin A.K. Osnovy teorii i elementy sistem avtomaticheskogo regulirovaniya [Basic Theory and Elements of Automatic Control Systems]. Moscow, Metallurgy Publ., 1987. 270 p.

2. Skarzhepa V.A., Shelekhov K.V. Tiristornye tsifrovye regulyatory temperatury [Thyristor Digital Temperature Controllers]. Kiev, Technics Publ, 1979. 144 p.

3. Klyuev A.S., Lebedev A.T., Semenov N.P, Tovarnov N.G. Naladka avtomaticheskikh sistem i ustroystv upravleniya tekhnologicheskimi protsessami (spravochnoe posobie) [Setting Up of Automatic Systems and Process Control Devices (Handbook)]. Moscow, Energy Publ., 1977. 400 p.

4. Kopelovich A.P. Inzhenernye metody rascheta pri vybore avtomaticheskikh regulyatorov [Engineering Methods for Calculating under the Choice of Automatic Regulators]. Moscow, Metallurgizdat Publ, 1960. 190 p.

5. Glinkov G.M., Makovskiy V.A., Lotman S.L., M.R. Shapirovskiy M.R. Proektirovanie sistem kontrolya i avtomaticheskogo regulirovaniya metallurgicheskikh protsessov: uch. posobie [Designing of Control Systems and Automatic Control of Metallurgical Processes: Tutorial]. Moscow, Metallurgy Publ., 1986. 352 p.

6. Komissarchik, V.F. Avtomaticheskoe regulirovanie tekhnologicheskikh protsessov: uch. posobie [Automatic Control of Technological Processes: Tutorial]. Tver: Tver State Technical University Publ., 2011. $248 \mathrm{p}$.

7. Panferov V.I. [Estimation of Dynamic Properties of a Control Object on the Transfer Function of the Closed System]. News of Higher Education Institutions. Ferrous Metallurgy, 1999, no. 10, pp. 54-56. (in Russ.)

8. Panferov V.I. [The Numerical Calculation of Automatic Control Systems]. News of Higher Education Institutions. Ferrous Metallurgy, 1997, no. 4, pp 26-28. (in Russ.)

9. Panferov V.I. [Numerical Simulation and Adjustment of Automatic Control Systems]. News of Higher Education Institutions. Ferrous Metallurgy, 2004, no. 8, pp. 41-44. (in Russ.)

10. Matveykin V.G., Frolov S.V., Elizarov I.A. [Calculation of Static On-off Control Systems]. Devices and Control Systems, 1997, no. 6, pp. 33-36. (in Russ.) 


\title{
Управление в технических системах
}

11. Frolov S.V., Elizarov I.A., Loskutov S.A. [Comparative Analysis of the On-off Control Systems]. Industrial ACS and controllers, 2005, no. 9, pp. 33-37. (in Russ.)

12. Vokhryshev V.E., Kapustin I.A., Ragazin D.A. [Synthesis of Relay Adaptive Systems with Desired Levels of Quality]. Bulletin of the Samara State Technical University. Series Engineering, 2009, no 1, pp. 14-19. (in Russ.)

13. Ragazin, D.A. Analiz i sintez samonastraivayushchikhsya releynykh sistem upravleniya s peremennym gisterezisom: avtoreferat dis.kand. tehn. nauk [Analysis and Synthesis of Self-adjusting Relay Control Systems with Variable Hysteresis: the Dissertation Thesis for the Degree of Candidate of Technical Sciences]. Samara: Samara State Technical University Publ. 2011. 20 p.

14. Baklanov A.S., Vokhryshev V.E. [Relay system with variable structure and passive adaptation]. Bulletin of the Samara State Technical University. Series Engineering, 2015, no 2 (46), pp. 7-12. (in Russ.)

Received 1 August 2016

УДК 697.34:62-52

DOI: $10.14529 /$ ctcr160404

\section{К РЕШЕНИЮ ЗАДАЧИ КАЧЕСТВА НАСТРОЙКИ РЕЛЕЙНЫХ РЕГУЛЯТОРОВ}

\author{
С.В. Панферов ${ }^{1}$, Н.А. Тренин ${ }^{1}$, В.И. Панферов ${ }^{2}$ \\ ${ }^{1}$ Военный учебно-научный центр Военно-воздушных сил «Военно-воздушная академия \\ им. профр. Н.Е. Жуковского и Ю.А. Гагарина», филиал в г. Челябинске, \\ ${ }^{2}$ Южно-Уральский государственный университет, г. Челябинск
}

Рассматривается проблема настройки релейных систем автоматического регулирования (САР), включающих двухпозиционные и трехпозиционные Рп-регуляторы. Задача в целом решается методом прямого модельного анализа переходных процессов в САР. Для параметрической идентификации моделей объектов управления разработаны численные процедуры определения оптимальных параметров их дифференциальных уравнений как по экспериментальным кривым разгона, так и по переходным функциям работающих замкнутых систем. Предложены алгоритмы цифровой реализации релейных регуляторов. Приводится анализ результатов моделирования процессов в двухпозиционных и трехпозиционных системах. Результаты работы могут быть использованы для выбора настроек релейных регуляторов.

Ключевые слова: система автоматического регулирования, релейный регулятор, объект управления, параметрическая идентификация модели, качество настройки, численный расчет, переходный процесс, выбор параметров настройки.

\section{Лuтература}

1. Основы теории и элементы систем автоматического регулирования / В.Ю. Каганов, Г.М. Глинков, М.Д. Климовицкий, А.К. Климушкин; под ред. Г.М. Глинкова. - М.: Металлургия, 1987. $-270 \mathrm{c}$.

2. Скаржепа, В.А. Тиристорные ичирровые регуляторы температуры / В.А. Скаржепа, К.В. Шелехов. - Киев: Техника, 1979. - 144 с.

3. Наладка автоматических систем и устройств управления технологическими прочессами: справ. пособие / А.С. Клюев, А.Т. Лебедев, Н.П. Семенов, Н.Г. Товарнов; под ред. А.С. Клюева. М.: Энергия, 1977. - 400 c.

4. Копелович, А.П. Инженерные методы расчета при выборе автоматических регуляторов / А.П. Копелович. - М.: Металлургиздат, 1960. - 190 c. 
5. Проектирование систем контроля и автоматического регулирования металлургических процессов: учеб. пособие / Г.М. Глинков, В.А. Маковский, С.Л. Лотман, М.Р. Шапировский; под ред. Г.М. Глинкова. - М.: Металлургия, 1986. - 352 с.

6. Комиссарчик, В.Ф. Автоматическое регулирование технологических прочессов: учеб. пособие / В.Ф. Комиссарчик. - Тверь: Тверской ГТУ, 2011. - 248 с.

7. Панферов, В.И. Оиенка динамических свойств объекта управления по переходной функиии замкнутой системы / В.И. Панферов // Изв. вузов. Черная металлургия. - 1999. - № 10. - С. 54 - 56.

8. Панферов, В.И. Численный расчет систем автоматического регулирования./ В.И. Панферов // Изв. вузов. Черная металлургия. - 1997. - № 4. - С. 66-68.

9. Панферов, В.И. Численное моделирование и настройка систем автоматического регулирования / В.И. Панферов // Изв. вузов. Черная металлургия. - 2004. - № 8. - C. 41-44.

10. Матвейкин, В.Г. Расчет двухпозиционных статических систем регулирования / В.Г. Матвейкин, С.В. Фролов, И.А. Елизаров // Приборы и системы управления. - 1997. - № 6. - С. 33-36.

11. Фролов, С.В. Сравнительный анализ систем двухпозиционного регулирования / С.В. Фролов, И.А. Елизаров, С.А. Лоскутов // Промылиленные АСУ и контроллеры. - 2005. - № 9. - С. 33-37.

12. Вохрышев, В.Е. Синтез релейных самонастраивающихся систем с заданными показателями качества / В.Е. Вохрышев, И.А. Капустин, Д.А. Рагазин // Вестник Самарского государственного технического университета. Серия Технические науки. - 2009. - № 1. - C. 14-19.

13. Рагазин, Д.А. Анализ и синтез самонастраивающихся релейных систем управления с переменным гистерезисом: автореф. дис. ... канд. техн. наук / Д.А. Рагазин. - Самара: Изд-во СамГТУ, $2011-20 \mathrm{c}$.

14. Бакланов, А.С. Релейные системы с переменной структурой и пассивной адаптацией / А.С. Бакланов, В.Е. Вохрышев // Вестник Самарского государственного технического университета. Серия Технические науки. - 2015. - № 2 (46). - С. 7-12.

Панферов Сергей Владимирович, канд. техн. наук, доцент, Военный учебно-научный центр Военно-воздушных сил «Военно-воздушная академия им. проф. Н.Е. Жуковского и Ю.А. Гагарина», филиал в г. Челябинске.

Тренин Николай Александрович, канд. воен. наук, начальник кафедры, Военный учебнонаучный центр Военно-воздушных сил «Военно-воздушная академия им. проф. Н.Е. Жуковского и Ю.А. Гагарина», филиал в г. Челябинске.

Панферов Владимир Иванович, д-р техн. наук, профессор, Южно-Уральский государственный университет, г. Челябинск; tgsiv@mail.ru.

Поступила в редакцию 1 августа 2016 г.

\section{ОБРАЗЕЦ ЦИТИРОВАНИЯ}

Panferov, S.V. On the Solution of the Setting Quality Problem for the Relay Controllers / S.V. Panferov, N.A. Trenin, V.I. Panferov // Вестник ЮУрГУ. Серия «Компьютерные технологии, управление, радиоэлектроника». - 2016. - Т. 16, № 4. - C. 29-35. DOI: $10.14529 /$ ctcr 160404

\section{FOR CITATION}

Panferov S.V., Trenin N.A., Panferov V.I. On the Solution of the Setting Quality Problem for the Relay Controllers. Bulletin of the South Ural State University. Ser. Computer Technologies, Automatic Control, Radio Electronics, 2016, vol. 16, no. 4, pp. 29-35. DOI: $10.14529 /$ ctcr160404 